\title{
Development of Anecdote Text Teaching Material Based on Moral Value
}

\author{
Siti Umi Hani ${ }^{1, \text { *, }}$, Suherli Kusmana ${ }^{2}$, Yusida Gloriani ${ }^{2}$ \\ ${ }^{1}$ Posgraduate School, Swadaya Gunung Jati University, Cirebon, Indonesia \\ ${ }^{2}$ Teacher Training and Education Faculty, Swadaya Gunung Jati University, Cirebon, Indonesia
}

Email address:

Benazirbe19@gmail.com (S. U. Hani)

${ }^{*}$ Corresponding author

\section{To cite this article:}

Siti Umi Hani, Suherli Kusmana, Yusida Gloriani. Development of Anecdote Text Teaching Material Based on Moral Value. International Journal of Secondary Education. Vol. 9, No. 2, 2021, pp. 38-44. doi: 10.11648/j.ijsedu.20210902.11

Received: April 6, 2021; Accepted: April 19, 2021; Published: April 29, 2021

\begin{abstract}
The purpose of this study was to obtain anecdote digital teaching materials for senior high school students. The object of this research is the anecdote texts. The method used is the method of research and development. This research using ADDIE Development which consist of five steps: the analysis, the design, the development, the implementation, and the evaluation, the development product of this research is a digital teaching materials for anecdote text, including the text, the structure, the language, and the value. The study begins with a descriptive analysis of the anecdote text, namely the structure, language, and value. Meanwhile, the discourse study includes critical discourse analysis. From this study, anecdote text teaching materials for senior high schools were developed through validation and due diligence. The instrument of validations that has been developed validated by the experts and teachers including the Indonesian language teacher expert and digital media expert. The results of this research are anecdote text digital teaching material can be used as the basis for anecdote text teaching materials for learning. Anecdote teaching material can be developed into digital teaching materials and based on the validation test of Indonesian language teachers and experts, the teaching materials can be categorized as valid and suitable for use in learning.
\end{abstract}

Keywords: Anecdote Text, Teaching Materials, Digital Teaching Material

\section{Introduction}

The Indonesian language learning paradigm in the 2013 Curriculum is oriented towards text-based learning, which can be seen in the formulation of the basic competencies of the substance of Indonesian in secondary education, namely direct (continuous) text or single texts or micro genres, one type of text is anecdote. Anecdotal text material provides a new atmosphere and experience in Indonesian language learning. This text is important in its presence in Indonesian language learning because the elements contained in anecdotal texts are not only cognitive aspects of students, but also affective aspects. A learning atmosphere that is fun and full of humor will be created with the existence of anecdotal material on Indonesian language learning, students can express their feelings through anecdote text.

Anecdotal texts found in textbooks based on the 2013
Curriculum are a learning resource that can support learning. This can facilitate the work of the teacher in finding teaching materials for anecdotal texts. Teaching materials can ideally assist students in meeting the predetermined competency standards of graduates, namely (1) attitudes (2) skills and (3) knowledge. [1]

Learning resource materials are needed by students to be able to support cognitive, affective and psychomotor factors contained in the development of emotions, motor skills, visual observation and memory, hearing, passive and active language skills, and intelligence [2]. Therefore, educational resources in schools must master the concept of this new curriculum well. The presence of new material makes teachers less prepared for learning. Moreover, the teaching materials presented in the textbook have not met the learning needs in the classroom. The limitations of this teaching material can hinder the process of developing the implementation of the 2013 Curriculum in schools. Educators 
are expected to be able to find references and other sources so that the insights taught will be broader and more diverse. This is supported by the results of research before which states that modules or teaching materials carried out in learning activities still refer to the old curriculum. [3]

The delivery of teaching materials that are attractive and in accordance with the characteristics of students is also important in the learning process. Psychologically, vulnerable students aged 14-18 years tend to like things that are modern and sophisticated. These characteristics are the basis for teachers to find the right media. Media in accordance with these characteristics is digital media. Digital media may be more attractive and attractive to students compared to the use of the lecture method in class. The media used is in the form of teaching materials which contain anecdotal texts that are packaged digitally so as to attract students to learn more in different ways. Digital media is computer-based media. A computer with its facilities is certainly able to facilitate the various learning models desired by the teacher. The use of digital media is very useful to help the communication process between teachers and students be more effective.

Not all of the anecdotal texts circulating in the community have story meanings that are appropriate to be used as teaching material. In fact, all the jokes and anecdotes that circulate the most, especially among teenagers and students, are about sex [4] this is what makes researchers feel the need to do this research. Researchers try to help teachers find alternative teaching materials other than those already contained in the 2013 Curriculum textbooks so that educators do not carelessly use anecdotal texts circulating in the community. Indonesian is open in nature, which means that it is possible to be given new content according to the needs of today's education.

The analytical approach that is relevant to anecdotal texts is a paradigm approach. This approach is used to reveal how the satire implied in an anecdotal text. In other words, the paradigm seeks to examine all aspects of the meaning of speech which are not completely by direct reference to the truth conditions of the spoken sentence and cannot be explained semantically in the anecdotal text. Anecdotal text analysis is very appropriate when using pragmatics because to understand anecdotal text is not only funny, but also convey the wisdom implied in an interesting event in our life, it is necessary to understand the context behind the emergence of the humor. This research is very important to do, this is due to the impact of the current phenomenon of curriculum changes that are considered crucial and the time is right to do this research now. Moreover, this anecdotal text is something new in school learning, so it is felt that there have not been many studies that have developed anecdotal texts to be used as modern teaching materials in schools.

Based on this, research is needed that combines anecdotal texts based on moral values with a more modern delivery in accordance with the current digital era. Digital media is deemed in accordance with the characteristics of students. Anecdotal texts that are packaged through digital media are expected to be more effective and efficient in the learning process so that the results achieved are in accordance with the expectations of educators.

\section{Reference Review}

\subsection{Anecdote Text}

Anecdotes are short stories that are interesting because they are funny and impressive, usually about important or famous people and based on actual events [5]. Anecdotal texts are short stories that contain events that are annoying and ridiculous to participants who experience them. Feelings of annoyance and ridiculousness like that are crises that respond to the reaction of the conflict between comfortable and not, satisfied and frustrated, and achieved and failed.

In addition, anecdotes are fictional stories that do not have to be based on the facts that occur in society, the participants or actors in them do not have to be important people. Anecdotal texts also contain events that make you feel irritated or ridiculous. This feeling is a crisis that is responded to by the reaction of the conflict between comfort and discomfort, satisfaction and frustration, and achievement and failure. Anecdotes are also short stories that are interesting because they are funny and memorable, usually about important or famous people and based on actual events [6] Anecdotes are one of the literary genres that usually reflect on themselves and issues that are currently hot and become a phenomenon in social life.

Some definitions of the anecdotal text, it can be stated that anecdotal text is a text in the form of a story in which it contains elements of humor or humor and criticism, usually based on true or factual stories about famous figures.

In writing anecdotal texts, one must pay attention to a predetermined structure, as explained above, that the structure of an anecdotal text must be in the form of a short story or dialogue and has characters, settings and a series of events. The anecdotal text structure consists of: (1) Abstraction is a sign of what is told in the form of unusual, unusual, strange events, or in the form of a summary of what the text will tell or explain; (2) Orientation is an introduction or opening in the form of an introduction to a character, time and place; (3) Crisis is a problem arising;(4) Reactions are actions or measures taken in response to a problem.(5) Coda is a change that occurs in the character lessons that can be learned from the story, and (6) Reorientation is an expression that shows the story has ended [5].

Based on the structure of the anecdotal text that has been described, abstraction, orientation, crisis, reaction, coda, and reorientation constitute a complete unity in writing anecdotal texts. The author concludes that in writing anecdotal texts must use a predetermined and appropriate structure including plausible events, recognition of situations, problems, action on problems, and based on facts so that they can be used as lessons, advice to audiences.

\subsection{Digital Teaching Materials}

The success of the learning process is determined by many 
factors. Teaching materials are an important factor in addition to the factors of educators, students, facilities, and other components. The interaction between these components is very important in achieving the learning objectives designed by the teacher. Good teaching materials will be able to motivate students to study even harder and be able to develop the potential of students.

Teaching materials are all forms of material used to assist teachers / instructors in carrying out teaching and learning activities in the classroom. The material in question can be written or unwritten. [6] Teaching materials can also be interpreted as information, tools or texts that are needed or used by teachers to plan and study the implementation of learning. Teaching materials are all forms of material used to assist teachers or instructors in carrying out the learning process in the classroom. The material in question can be written or unwritten material. [3] The existence of teachers can be helped by teaching materials, such as books, modules, and other educational software that can be used for independent learning by students [7]

Teaching materials are a set of materials that are systematically arranged both written and unwritten so as to create an environment or atmosphere that allows students to learn such as textbooks, handouts, student worksheets, modules and so on. Another term states that teaching materials are all forms of material used to assist teachers or instructors in carrying out teaching and learning activities in class

Teaching materials are also all materials (both information, tools, and texts) that are arranged systematically, which displays a complete figure of competencies that will be mastered by students and used in the learning process with the aim of planning and analyzing the implementation of learning [8]

Teaching materials are a set of learning tools or tools that contain learning materials, methods, limitations, and ways of evaluating which are designed systematically and attractively in order to achieve the expected goals, namely achieving competencies or sub competencies with all their complexities. Teaching materials must be designed and written in instructional principles because they will be used by teachers to help and support the learning process Materials or learning materials are basically the "content" of the curriculum, namely in the form of subjects or fields of study with topics / sub topics and their details

Teaching materials must present material that can encourage students to actively learn. Teaching materials that are arranged must pay attention to the objectives of the teaching. Therefore, the main task of teachers in learning is to turn students into readers. [9] Teaching materials must provide opportunities and flexibility for students. The reader's activity is to determine the meaning of a text [10] Text is a state of silence, helplessness, only opens the opportunity for the reader to enter and speak with his heart and mind.

Meanwhile, in learning, teaching materials must be arranged by constructing the knowledge and insights of students previously obtained. Then they try to solve the problem in groups by discussing with other students. [11]

From the definitions mentioned above, learning media such as books, videos, audio programs, or computers that contain lessons that are deliberately designed systematically, then these materials are called teaching materials. However, if it is not systematically designed even though it contains subject matter, it cannot be called teaching material. This shows the location of the difference between teaching materials and non-teaching materials.

Teaching materials are designed in such a way as to pay attention to the type, scope, sequence and treatment [12] the type of learning material also needs to be identified appropriately. Because each type of teaching material requires different media, evaluation techniques, and methods. The depth of the material or scope needs to be considered so that the material is neither less nor more. The order of teaching materials must also be considered so that the learning process is coherent. In addition, the treatment of teaching materials needs to be chosen appropriately so that teaching materials can be identified (what materials need to be memorized, understood, and applied) [12] This is necessary so that a teacher is not mistaken in delivering the teaching material to students.

Educational technology is the study and ethics of practice to facilitate learning and improve performance by creating, using, and managing fast processes and resources and technology. Referring to this definition, the development of teaching materials is included in the creating area. [13]

The presence of educational technology in education is generally intended to facilitate learning. The main purpose of educational technology is to identify and solve problems related to learning problems. Therefore, the main principle of educational technology is to pay attention to the interests of students, while the main principle of education is to help improve the efficiency of the learning process. The efficiency of the learning process as intended, can be achieved if the learning interaction refers to learning activities and learning situations according to the abilities of students.

In the perspective of educational technology, learning resources are recognized as the most important component of learning. Learning resources consist of six components, namely: messages, people, teaching materials, equipment, techniques, and the environment [14] among the six components of learning resources, the most dominant is teaching materials for students. In terms of educational technology, the development of teaching materials is an effort to fulfill the function of developing learning resources, so that learning problems can be overcome.

The development of teaching materials is a systematic activity in producing learning products in the form of textbooks, which is carried out in stages based on the stages of the learning system design. This stage begins with a needs analysis, designing, developing, implementing, and evaluating the product. This development stage will produce teaching materials that are suitable for use in learning [15].

The P2M LPPM UNS team stated that the electronic module is a learning tool or tool that contains materials, 
methods, limitations, and ways of evaluating which are designed systematically and attractively to achieve the expected competencies. One form of presenting study materials in digital or electronic format is an e-book. An electronic book or e-book is an electronic version of a printed book, read using electronic devices and special software.

E-books encourage a combination of print technology with computer technology in learning activities. Various printed learning media, one of which is a module whose presentation can be changed into electronic form, thus giving birth to the term electronic module or what is known as e-module. Thus, the electronic module can be defined as a form of presenting independent learning materials that are systematically arranged into learning units to achieve certain learning objectives presented in an electronic format.

\subsection{Moral Value}

Relates to the ability to distinguish between right and wrong actions, thus, moral values can be interpreted as the result of good deeds performed by someone. The word moral always refers to the pros and cons of humans as humans [1] The notion of moral does not only refer to the good and the bad, for example as a lecturer, cook, badminton player or lecturer, but as a human being who is responsible for his profession. The moral field is the field of human life in terms of its goodness as a human being. Moral norms are a yardstick to determine whether or not human attitudes and actions are seen in terms of their merits as a human being and not as a certain and limited role actor.

Moral is basically a series of values about various kinds of behavior that must be obeyed. Moral is the rule of norms and institutions that regulate individual behavior in relation to social groups and society. Moral is a standard of good and bad that is determined for the individual socio-cultural values where the individual is a social member. Morality is an aspect of personality that is needed by a person in relation to social life in a harmonious, fair and balanced manner. Moral behavior is necessary for the realization of a peaceful life full of order, order and harmony. [16]

In conclusion, morals are all good actions and bad actions on humans that are formed because of a habit, while ethics is the science of principles or norms. So good and bad habits are what make good morals and bad morals, therefore a habit will crystallize or shape a person's morals.

Supposedly, morals are needed in community life in socializing. Individuals view other individuals or groups based on morals. Regarding behavior, politeness, being kind are some of the moral attitudes seen by society. Morals can view society as having good or bad social values. A person's personality is very closely related in daily activities, morals are needed for a peaceful and harmonious life according to the rules. It can be understood that morals are the whole rules, rules or laws in the form of orders and prohibitions that regulate human behavior and the society in which humans exist. Therefore, moral is a regulator of individual behavior in socializing with community groups.

\section{Method}

The research method used is research and development as developed [17]. From this study produced valid and effective teaching material products [18]. The research and development method is a research method used to produce a certain product and test the effectiveness of the product [19].

The development model used is the ADDIE development model. The development stages in this model are the same as the standard development stages, but this model is specifically designed for multimedia-based learning. This is very suitable for the product to be developed. The stages of development with the ADDIE model are Analyze, Design, Development, Implementation, and Evaluation [20]

Data collection techniques in this study consisted of questionnaires, documentation and interviews. Primary data sources were obtained through documentation and literature study with the help of print media and internet (digital) media as well as field notes taken directly from the source without any intermediaries. Meanwhile, secondary data sources were obtained through interviews and direct field observations. The analysis was carried out with data obtained from a questionnaire given to media experts, material experts, educators and student responses.

\section{Analysis and Discussion}

\subsection{Analysis of Teacher Needs Data}

Teaching materials have an important role in realizing learning activities in schools, learning is presented and processed by teachers to be conveyed to students in order to achieve learning objectives. To achieve learning objectives in each basic competency, teaching materials are needed as references / guidelines that are in accordance with the curriculum. This triggers the teacher to look for teaching materials related to the 2013 curriculum material as much as possible and sort out the media that will be used carefully.

\subsection{Analysis of the Validation Questionnaire Data for Teaching Materials}

The calculation of the assessment questionnaire uses the feasibility calculation formulas as follows.

Table 1. Questionnaire Assessment Criteria.

\begin{tabular}{ll}
\hline Calculation Percentage & Assessment Criteria \\
\hline $85.01 \%-100.00 \%$ & Very valid, or can be used without revision \\
$70.01 \%-85.00 \%$ & Quite valid, or can be used but needs a little revision. \\
$50.01 \%-70.00 \%$ & Less valid, it is recommended not to use it because it needs a lot of revision. \\
$01.00 \%-50.00 \%$ & Not valid, or may not be used \\
\hline
\end{tabular}


Determine the value (\%) of the eligibility criteria for teaching materials using the following formula.

$$
\text { Assessment Result }=\frac{T S e}{T S h} \times 100 \%=\ldots \%
$$

Description:

TSe: results obtained from the questionnaire

TSh: maximum value of the entire questionnaire

Material expert validating the development of anecdotal text teaching materials for class students X Senior/Vocational High School is an expert in Indonesian Language and Literature education. In this study, material experts who were involved to validate non-textbooks, namely Dr. Indriya Mulyaningsih, M. Pd. who is a lecturer in Indonesian Language and Literature education at IAIN Syekh Nurjati Cirebon. Her selection as a validator was based on the advice of his supervisor and his qualifications in the field of teaching Indonesian Language and Literature. The aspects that become the assessment in the validation of the development of teaching materials include: 1) aspects of the feasibility of the content, 2) aspects of language, 3) aspects of the presentation of teaching materials, 4) scarcity. The following is an explanation of the validation results and suggestions for improvement of each aspect of the development of Anecdote Text teaching materials in Senior/Vocational High School by material experts.

Based on the results of the material expert assessment questionnaire which contains questions about aspects of the development of anecdotal text teaching materials in vocational schools, the following results are obtained: eligibility of content gets a score of 25 , language gets a score of 14 , presentation gets a score of 38 , and graphs get a score of 12 so that the overall score is obtained 89 of the total maximum value of 100 . Based on the value obtained, the summation that can be done is as follows.

$$
\text { Assessment Result }=\frac{89}{100} \times 100 \%=89 \%
$$

Total score obtained by a percentage value of $89 \%$ from the questionnaire of material expert judgment on anecdotal text teaching materials. Thus, the eligibility criteria for teaching materials obtained based on the average score of the questionnaire showed that the development of anecdotal text teaching materials in Senior/Vocational High School was very valid. However, there are still revisions to certain parts of the teaching materials and need to be added.

Researchers also validated the development of anecdotal text teaching materials in digital form by media experts. Digital media experts who validate the development of anecdotal text teaching materials in digital form for grade X Senior/Vocational High School are computer science experts. In this study, media experts who were involved to validate anecdotal text teaching materials in digital form, namely Abdun Wijaya, M. Kom. Who is a lecturer in computer science education at Catur Insan Cendikia University, His selection as a validator was based on the advice of his supervisor and his qualifications in computer and digital science. The aspects that become the assessment in the validation of the development of teaching materials include: 1) aspects of the feasibility of the content, 2) aspects of language, 3) aspects of the presentation of teaching materials, 4) scarcity. The following is an explanation of the validation results and suggestions for improvement of each aspect of the development of Anecdote Text teaching materials in Senior/Vocational High School by media experts.

Based on the results of the media expert's assessment questionnaire which contains questions about aspects of the development of anecdotal text teaching materials in Senior/Vocational High School, the scores are as follows: the content's appropriateness gets a score of 24 , language gets a score of 16, presentation gets a score of 33 , and graphs get a score of 12 so that the overall score is obtained. With a total of 85 of the maximum total value of 100 . Based on the value obtained, the summation that can be done is as follows.

$$
\text { Assessment Results }=\frac{85}{100} \times 100 \%=85 \%
$$

Based on the results of the total score, a percentage value of $85 \%$ was obtained from the material expert's assessment questionnaire on anecdotal text teaching materials. Thus, the eligibility criteria for teaching materials obtained based on the average score of the questionnaire show that the development of anecdotal text teaching materials at Senior/Vocational High School is quite valid. However, there are still revisions to certain parts of the teaching materials and need to be added.

The development of anecdotal text teaching materials in digital form was also validated by 11 teachers as education practitioners. Educational practitioners who are scattered in several regions validate the development of anecdotal text teaching materials as an assessment material in the feasibility of teaching materials in digital form for grade $\mathrm{X}$ Senior/Vocational High School students. In this study, 11 teachers were involved in validating anecdotal text teaching materials in digital form. The selection of 11 teachers as validators based on their qualifications as professional teachers is proven by an educator certificate. As for the aspects that are assessed in the validation of the development of teaching materials include: 1) aspects of content feasibility, 2) aspects of language, 3) aspects of the presentation of teaching materials, 4) martyrdom. The following is an explanation of the results of validation and suggestions for improvement of each aspect of the development of Anecdote Text teaching materials in Senior/Vocational High School. Based on the results of the 11 teacher questionnaire assessment which contains questions about aspects of teaching materials such as aspects of ease / use, language, module content / material and satisfaction. Charts and displays). Then the overall value can be obtained with the sum of 892 from the maximum total value of 990 . with the details of the assessment of each respondent as follows (G-1) 70, (G-2) 81, (G-3) 86, (G-4) 88, (G-5) 73, (G6) 90, (G-7) 73, (G-8) 73, (G-9) 90, (G-10) 73, and (G11) 90. 
The sum that can be obtained is as follows.

$$
\text { Assessment Result }=\frac{892}{990} \times 100 \%=90,10 \%
$$

Based on the results of the calculation, it can be obtained an average value of $90.10 \%$ from the teacher's assessment questionnaire on the feasibility of anecdotal text teaching materials as vocational school teaching materials. Thus the teacher's response to the feasibility of teaching materials obtained based on the average score of the questionnaire shows that the teaching materials are very valid and can be used without revision.

\section{Conclusion}

Based on the research conducted, it can be concluded as follows:

1. The teaching materials used for learning anecdotal texts in Indonesian language learning are taken from 2013 curriculum textbook. Teachers have not used digital anecdotal text teaching materials as other guidelines besides the Ministry of Education and Culture's 2013 curriculum textbooks. For this reason, the teacher looks for examples of anecdotal texts from other media besides the 2013 curriculum textbook. The design of digital-based anecdotal text teaching materials that have moral values has fulfilled the following matters: honesty, being oneself, responsible, independent, moral courage, humility and critical.

2. Characteristics of anecdotal texts have an abstraction structure of the crisis reaction orientation code. An abstract in the form of an opening story that will describe the beginning of the story. Orientation is a review that describes the initial situation of the story. Orientation will build the context of the reader to a story. Crisis is a part of the story that describes an urgent situation or the occurrence of conflict experienced by a character (the occurrence of dissatisfaction or irregularities). Reaction, namely the character's response to the conflict that arises. Coda is the ending of the story or the state of the ending.

3. Teaching materials have been declared feasible by validation of Indonesian language material experts with a percentage value of $89 \%$ of the material expert's assessment questionnaire on anecdotal text teaching materials. Thus, the eligibility criteria for teaching materials obtained based on the average score of the questionnaire showed that the development of anecdotal text teaching materials in Senior/Vocational High School was very valid. However, there are still revisions to certain parts of the teaching materials and need to be added.

4. Based on the results of the media expert's validation, the total score obtained was a percentage value of $85 \%$ from the questionnaire for the material expert's assessment of the anecdotal text teaching materials. Thus, the eligibility criteria for teaching materials obtained based on the average score of the questionnaire showed that the development of anecdotal text teaching materials in Senior/Vocational High School was quite valid. However, there are still revisions to certain parts of the teaching materials and need to be added.

5. The results of the validations by 11 teachers obtained a score of 892 and a maximum score of 990 in the questionnaire assessment. So that the average value of feasibility was obtained at $90.10 \%$. Thus, it can be obtained that the eligibility criteria for anecdotal text teaching materials as teaching materials for class $\mathrm{X}$ in Senior/Vocational High School based on the average value of the questionnaire shows that the digital teaching materials have very valid eligibility and can be used without revision.

\section{References}

[1] Tim Depdiknas. 2013. Kurikulum 2013 Mata Pelajaran Bahasa Indonesia. Jakarta: Depdiknas.

[2] Hamid, Hamdani, 2013, Pengembangan Sistem Pendidikan di Indonesia. Bandung: Pustaka Setia.

[3] Andi Prastowo, 2012, Panduan Kreatif Membuat Bahan Ajar Inovatif, Yogyakarta: Diva Press.

[4] Sitepu, 2012, Penulisan Buku Teks Pelajaran, Bandung: Remaja Rosdakarya.

[5] Tim Kemendikbud. 2013. Buku Siswa Bahasa Indonesia Kelas X Ekspresi Diri dan Akademik. Jakarta: Kemendikbud.

[6] Mudlofar, Ali, 2012, Aplikasi Pengembangan Kurikulum Tingkat Satuan Pendidikan dan Bahan Ajar dalam Pendidikan Islam, Jakarta: Rajawali Pers.

[7] Banamtuan, Maglon Ferdinand. 2021. Pengembangan Bahan Ajar Berbasis e-Book Menggunakan Aplikasi 3D Pageflip Standar. Jurnal Pendidikan, Volume 2, No 1, Pebruari 2021 (16-25) e-ISSN 2721-1622.

[8] Tim Kemendikbud. (2014). Bahasa Indonesia Wahana Pengetahuan. Jakarta: Kemedikbud.

[9] Rozak, Abdul. 2009. Penilaian Yang Berkeadilan dan Berdaya Ungkap Kompetensi Teruji; Kasus Dalam Pembelajaran Apresiasi Sastra. Jurnal terbit 16/01/2009 Repository FKIP Unswagati. https//scholar.google.co.id/citation

[10] Rozak, Abdul. (2014). Membaca Kehidupan Melalui Teks Puisi. Jurnal terbit 22/12/2014 Repository FKIP Unswagati. https://scholar.google.co.id/citations

[11] Kusmana, Suherli. 2016. Orientasi Mata Pelajaran Bahasa Indonesia dalam Kurikulum 2013. Yogyakarta: Program Studi Pendidikan Bahasa dan Sastra Indonesia Fakultas Keguruan dan Ilmu Pendidikan Universitas Ahmad Dahlan.

[12] Haryati, Titik dan Noor Rochman. 2012. Peningkatan Kualitas Pembelajaran Pendidikan Kewarganegaraan Melalui Praktik Belajar Kewarganegaraan (Project Citizen). Jurnal Ilmiah CIVIS Vol. II No. 2, Juli.

[13] Januszewski and Molenda. 2008. Educational Technologi A definition with Commentary. USA: Taylor \& Francis Group, LLC. 
[14] Raharjo, Jajo Firman. 2021. Pelatihan E-learning Dan Pembuatan Buku Ajar Digital Bagi Peningkatan Peran Guru Millenial, Jurnal Abdi Masyarakat UMUS Vol. 1, No. 02, Februari 2021, pp. 113 121.

[15] Rafiudin, dkk, 2021. Pelatihan Pengembangan Bahan Ajar Elektronik (E-Book) di SMKN 1 Banjarmasin, Jurnal Pengabdian Masyarakat ISSN: 2722-3043 (online) ISSN: 2722-2934 (print), Vol 3 No 12021 Hal 9-15.

[16] Mohammad Ali dan Mohammad Asrori, 2012, Psikologi Remaja; Perkembangan Peserta Didik, Jakarta: Bumi Aksara
[17] W. R. Borg \& M. D. Gall, Educational Research: An Introduction, Fifth Edition. New York: Longman. 1983.

[18] N. S. Sukmadinata, Metode Penelitian Pendidikan. Bandung: Remaja Rosda Karya dan Program Pascasarjana UPI Bandung. 2010.

[19] Sugiyono. 2017. Metode Penelitian Kuantitatif, Kualitatif, dan R\&D. Bandung: Alfabeta.

[20] Pribadi, Benny A. 2014. Desain dan Pengembangan Program Berbasis Kompetensi Implementasi Model ADDIE. Jakarta: Prenada Media Grup BP. 